\title{
Recent Books in Public Opinion and Survey Methods
}

\section{Mario Callegaro}

Tags: survey practice

\section{Survey Practice}

Vol. 2, Issue 3, 2009

Recent Books in Public Opinion and Survey Methods

Bell, R.M. and M.L. Cohen, eds. 2008. Coverage measurement in the 2010 census. National Academies Press, Washington, DC.

Belli, R.F., F.P. Stafford and D. F. Alwin, eds. 2009. Calendar and time diary methods in life course research. Sage, Los Angeles.

Brace, I. 2008. Questionnaire design: how to plan, structure and write survey material for effective market research. Kogan Page, Philadelphia.

Brown, L.D. M.L. Cohen and D.L. Cork. eds. 2008. Experimentation and evaluation plans for the 2010 census: interim report. National Academies Press, Washington, DC.

Carballo, M. and U. Hjelmar, eds. 2008. Public opinion polling in a globalized world. Springer, Berlin.

Conrad, F.G. and M.F. Schober, eds. 2008. Envisioning the survey interview of the future. Wiley, New York.

Converse, J.M. 2009 reprint. Survey research in the United States: roots and emergence 1890-1960. Transaction Publishers, Edison, NJ.

Couper, M.P. 2008. Designing effective web surveys. Cambridge Press, Cambridge.

de Leeuw, E.D., J.J. Hox and D.A. Dillman, eds. 2008. International handbook of survey methodology. Lawrence Erlbaum, New York.

Dillman, D.A., J.D. Smyth and L.M. Christian. 2009. Internet, mail and mixed-mode surveys: the tailored design method (3rd ed.). Wiley, Hoboken, NJ.

Donsbach, W. and M.W. Traugott, eds. 2008. The Sage handbook of public opinion research. Sage, Los Angeles. 
Fielding, N. 2008. Interviewing II. Four volume set. Sage, Los Angeles.

Fielding, N., R.M. Lee and G. Blank, eds. 2008. The Sage bandbook of online research methods. Sage, Los Angeles.

Fowler, F.J. 2008. Survey research methods (4th ed.). Sage, Los Angeles.

Groves, R.M. and D.L. Cork. 2008. Surveying victims: options for conducting the national crime victimization survey. National Academies Press, Washington, DC.

Groves, R.M., F.J. Fowler, M.P. Couper, et al. 2009. Survey methodology (2nd ed.). Wiley, New York.

Hernnson, P.S., R.G. Niemi, M.J. Hanmer, et al. 2008. Voting technology: the not-so-simple act of casting a ballot. Brookings Institution Press, Washington, DC.

Hesse-Biber, S.N. and P. Leavy, eds. 2008. Handbook of emergent methods. Guilford, New York.

Krueger, R.A. and M.A. Casey. 2009. Focus groups: a practical guide to applied research (4th ed.). Sage, Los Angeles.

Kulas, J.T. 2008. SPSS essentials: managing and analyzing social sciences data. Jossey-Bass, New York.

Lavrakas, P.J., ed. 2008. Encyclopedia of survey research methods. Sage, Los Angeles.

Lepkowski, J.M., C. Tucker, M.J. Brick, et al., eds. 2008. Advances in telephone survey methodology. Wiley, New York.

Levy, P. and S. Lemeshow. 2008. Sampling of populations: methods and applications (4th ed.). Wiley, New York.

Lynn, P., ed. 2009. Methodology of longitudinal surveys. Wiley, New York.

Marshall, T.R. 2008. Public opinion and the Rebnquist court. State University of New York Press, Albany, NY.

Moore, D.W. 2008. The opinion makers: an insider reveals the truth bebind the polls. Beacon, Boston.

Roberts, C. and R. Jowell. 2008. Attitude measurement. Four volume set. Sage, Los Angeles.

Scheuren, F.J. and W. Alvey, eds. 2008. Elections and exit polling. Wiley, New York.

Schuman, H. 2008. Method and meaning in polls and surveys. Harvard University Press, Cambridge. 
Traugott, M.W. and P.L. Lavrakas. 2008. The voter's guide to election polls (4th ed.). Rowman \& Littlefield, Lanham, MD.

Treiman, D.J. 2009. Quantitative data analysis: doing social research to test ideas. Jossey-Bass, New York.

Vander Stoep, S.W. and D.D. Johnson. 2009. Research methods for everyday life: blending qualitative and quantitative approaches. Jossey-Bass, New York.

Walden, G.R. 2008. Focus groups, volume I: a selective annotated bibliography. Art and bumanities, social sciences, and the nonmedical sciences. Scarecrow Press, Lanham, MD.

Winter, N.J. 2008. Dangerous times: How ideas about race and gender shape public opinion. University of Chicago Press, Chicago. 